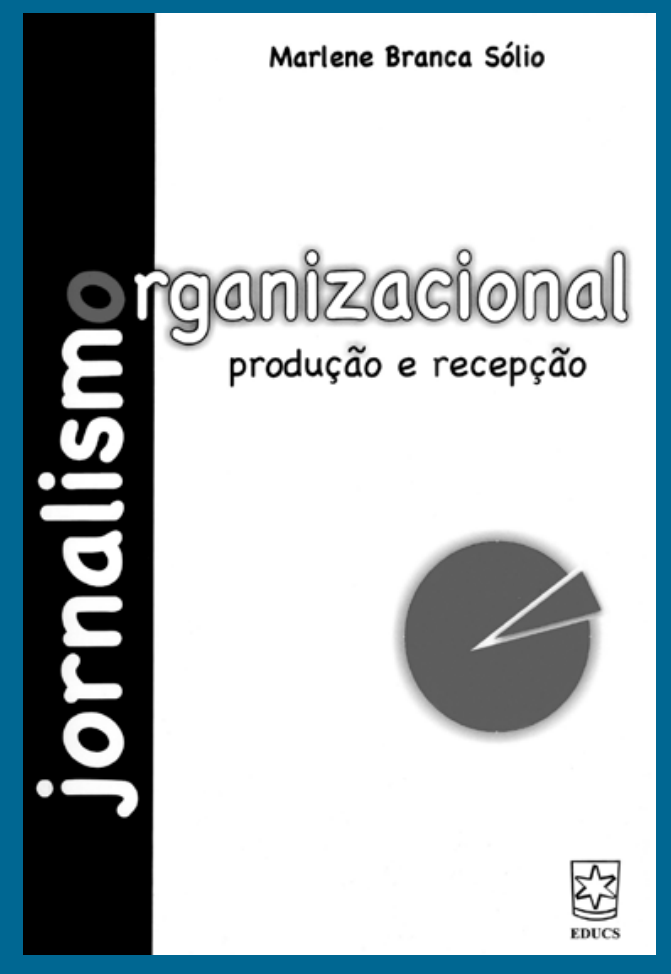

Jornalismo Organizacional (produção e recepção)

Marlene Branca Sólio

Caxias do Sul:

Editora da Universidade de Caxias do Sul, 2008.

158 páginas

Resenhado por:

Paulo Nassar

- Mestre e doutor pela Escola de Comunicações e Artes da Universidade de São Paulo (ECA-USP)

- Professor e coordenador do curso de Relações Públicas da ECA-USP

- Em nível de pós-graduação, é professor do programa de Ciências da Comunicação da ECA-USP

- Diretor-geral da Associação Brasileira de Comunicação Empresarial (ABERJE)

- paulonassar@usp.br 


\section{Jornalismo Organizacional em movimento}

Equando o jornalismo enfrenta questões radicais, que colocam em jogo seus - processos de produção, formas de veiculação, relação com o leitor, principalmente os tradicionais meios (jornais e revistas), - em um Brasil, que acaba de ver a morte da obrigatoriedade do diploma de jornalista, como chave legal e exclusiva de exercício da profissão, o que parece simbolizar a perda de centralidade da atividade, como único produtor de conteúdo noticioso - chega aos comunicadores e pesquisadores da Comunicação Organizacional e das Relações Públicas o livro "Jornalismo Organizacional (produção e recepção)", de Marlene Branca Sólio, pela Editora da Universidade de Caxias do Sul, resultado de sua dissertação de mestrado defendida na Universidade do Vale do Rio dos Sinos, de São Leopoldo (RS).

Além dos fatos narrados, os leitores se transformaram no mundo todo em críticos daquilo que antes consumiam passivamente. Por exemplo, desconfiam das mensagens veiculadas pelas mídias do chamado "quarto poder". São leitores, e também empresas e instituições, que veiculam suas mensagens através de meios próprios e ágeis como o blog e o Twitter, que corroeu o poder de produção e veiculação de informações do jornalismo tradicional, que agora tem uma concorrência abrangente e marcada pela diversidade de pontos-devista, principalmente em relação a temas complexos do cotidiano. Os nãojornalistas, em escala global, produzem conteúdo. Neste contexto, e cada vez mais, os antigos receptores parecem não querer mais intermediários. Eles são os próprios narradores de suas histórias; eles são a própria mídia.

\section{Muito além da informação}

Essa realidade, em que informação é commodity, gera a necessidade de um jornalismo que saiba selecionar a informação de interesse do leitor, seja um interprete qualificado dela e mais, opine com segurança.

O despreparo do jornalista e do veículo em responderem às novas demandas, com competência, fez desaparecer, nos últimos tempos e no âmbito da comunicação de massa, dezenas de revistas e jornais.

A consagrada revista inglesa Economist registrou o fechamento de 70 jornais na Inglaterra, a partir de 2008. No Brasil, em 2009, o jornal Gazeta Mercantil, ao completar nove décadas de existência, encerrou suas atividades, quase sem se ouvir lamentações. Também no âmbito das empresas esse movimento se repete, empresas como Vale, Petrobras, Votorantim e Natura, entre outras, descontinuaram ou reestruturaram publicações impressas, como resposta às mudanças econômicas, tecnológicas e comportamentais da sociedade e, consequentemente, de seus públicos. Veremos outras a cerrar portas, mas o jornalismo, como atividade e pensamento, continuará firme e relevante socialmente, desde que repensado, principalmente nos aspectos tecnológicos, profissionais 
e políticos. Para empresas e instituições, que têm no jornalismo um processo importante para divulgar e operar políticas, planejamento e ações organizacionais, é crucial que seus comunicadores avaliem as transformações do jornalismo em seu ambiente.

É isso que faz Marlene Branca Sólio, em seu Jornalismo Organizacional (produção e recepção). Ao observar e analisar os jornais internos de empresas de Caxias do Sul (RS), interpretar seus rituais de produção e o conjunto de pesquisas em profundidade, aplicado junto aos trabalhadores leitores, Branca Sólio desenhou um arco analítico - da produção até o leitor -, do qual se pode concluir que o jornalismo organizacional brasileiro avançou nas técnicas, mas caminhou pouco em direção à Comunicação Organizacional democrática, liberta da manipulação e prepotência, que olha para os públicos como objetos inanimados para os quais direciona uma comunicação medíocre e padronizada. Este estado em que se encontra a produção dos periódicos organizacionais leva a autora (2008, p. 151-152) a propor aos gestores, comunicadores e acadêmicos, uma reflexão sobre três aspectos, que envolvem o presente e o futuro desses veículos de comunicação:

"• a pouca importância que a academia, e mais especificamente as próprias escolas de comunicação, dedica ao jornalismo organizacional, que ocupa reduzido espaço nos currículos dos cursos e produções cientificas, justamente num momento em que se configura uma nova arquitetura, um novo formato tanto nas relações trabalhistas (jornalistas ainda são preparados para ocupar redações), quanto no espaço da comunicação (pelo menos teoricamente), dentro das organizações.

- a falsa premissa de que o jornalismo organizacional não apresenta tensionamentos, dificuldades e percalços para o profissional que se disponha, de fato, a desenvolver um bom trabalho. O jornalismo organizacional pode e deve receber um novo olhar dos profissionais. Nesse fazer jornalistico tem-se um veículo, tem-se o público e se tem o fato. Na verdade, o que menos se tem é a presença do verdadeiro profissional, que, por preconceito e talvez falta de reflexão sobre seu papel social, vem deixando uma brecha, num espaço por demais importante. Ao olhar para o jornalismo organizacional, deve-se refletir sobre a importância de seu papel social. À medida que um olhar mais crítico, sério e responsável recair sobre esse 'fazer jornalístico', ter-se-á constituído um espaço de grande importância.

- A pouca importância que os departamentos/setores de RH atribuem aos processos de comunicação como elementos fundamentais da administração nas/ das organizações."

Essa reflexão desacomoda do âmbito do fazer jornalístico o debate sobre as publicações organizacionais e o coloca nos âmbitos da administração, do ensino de relações públicas e de jornalismo, responsáveis e protagonistas nas decisões técnicas, éticas e estéticas da comunicação de empresas e instituições no Brasil. 